(c) American Dairy Science Association, 2005.

\title{
Changes in Chemical Composition of Alxa Bactrian Camel Milk During Lactation
}

\author{
H. Zhang, ${ }^{1}$ J. Yao, ${ }^{1}$ D. Zhao, ${ }^{1}$ H. Liu, ${ }^{1}$ J. $\mathrm{Li}{ }^{2}$ and M. Guo ${ }^{2}$ \\ ${ }^{1}$ College of Food Science and Engineering, Inner Mongolia Agriculture University, \\ Hohhot, Inner Mongolia, China \\ ${ }^{2}$ Department of Nutrition and Food Sciences, University of Vermont, Burlington 05405
}

\section{ABSTRACT}

Changes in chemical composition of Alxa bactrian camels reared in Inner Mongolia (China) during lactation were investigated. Colostrum and milk samples from 10 nomadic female camels in their first season of lactation were collected periodically from parturition until $90 \mathrm{~d}$ postpartum (PP). The average contents of gross composition were $14.23 \%$ protein, $4.44 \%$ lactose, $0.27 \%$ fat, $0.77 \%$ ash, and $20.16 \%$ total solids in colostrum at $2 \mathrm{~h} \mathrm{PP}$, and the respective mean values were $3.55,4.24,5.65,0.87$, and $14.31 \%$ for regular milk on d 90. A 15-fold increase was shown in fat content during the first $24 \mathrm{~h}$, whereas a sharp decrease was shown during the first $12 \mathrm{~h}$ of lactation in protein, ash, and total solids contents. Variation in lactose content was small (4.24 to $4.71 \%$ ) throughout the study period. Total $\mathrm{N}$, nonprotein $\mathrm{N}$, casein $\mathrm{N}$, and whey protein $\mathrm{N}$ were found to be 2.23, 0.06, 0.86, and $1.31 \mathrm{~g} / 100 \mathrm{~mL}$ for the colostrum at $2 \mathrm{~h}$ PP; and $0.56,0.04,0.45$, and $0.07 \mathrm{~g} /$ $100 \mathrm{~mL}$ for the milk at $90 \mathrm{~d}$ PP. Percentages of caseins increased steadily, whereas whey proteins declined gradually until 3 mo of lactation. Gas liquid chromatography analysis of milk fat showed that the content of even-numbered saturated fatty acids $\left(\mathrm{C}_{12: 0}-\mathrm{C}_{18: 0}\right)$ in camel colostrum ( $2 \mathrm{~h}$ to $7 \mathrm{~d} \mathrm{PP}$ ) was lower than that of regular milk ( 15 to $90 \mathrm{~d} \mathrm{PP}$ ). The predominant saturated fatty acids were $\mathrm{C}_{14: 0}, \mathrm{C}_{16: 0}$, and $\mathrm{C}_{18: 0}$, regardless of the stage of lactation. There was a considerable level of polyunsaturated fatty acids (mainly $\mathrm{C}_{18: 1}$ ) in Alxa camel's milk fat. The levels of $\mathrm{Ca}, \mathrm{P}, \mathrm{Na}, \mathrm{K}$, and $\mathrm{Cl}$ were $222.58,153.74,65.0,136.5$, and $141.1 \mathrm{mg} / 100 \mathrm{~g}$, respectively, at $2 \mathrm{~h} \mathrm{PP}$; the values of the minerals were $154.57,116.82,72.0,191.0$, and $152.0 \mathrm{mg} / 100 \mathrm{~g}$, respectively, for the regular milk on d 90 . The levels of vitamins $\mathrm{A}, \mathrm{C}, \mathrm{E}, \mathrm{B}_{1}, \mathrm{~B}_{2}, \mathrm{~B}_{6}$, and $\mathrm{D}$ were $0.97,29.60,1.45$, $0.12,1.24,0.54 \mathrm{mg} / \mathrm{L}$, and $640 \mathrm{IU} / \mathrm{L}$, respectively, in Alxa camel milk at $90 \mathrm{~d} P$ P. Vitamin A and C contents were higher and vitamins $\mathrm{E}$ and $\mathrm{B}_{1}$ were lower than

Received April 12, 2005.

Accepted June 2, 2005.

Corresponding author: Mingruo Guo; e-mail: mguo@uvm.edu. those in colostrum. Sodium dodecyl sulfate-PAGE and densitometry results demonstrated that Alxa camel colostrum is rich in immunoglobulins, serum albumin, and 2 unknown fractions, which are reduced in amount (\%) within $2 \mathrm{~d}$ of lactation. It seems that there is lack of $\beta$-lactoglobulin in Alxa camel milk, whereas casein and $\alpha$-lactalbumin start at a low level and increase gradually until they reach their regular levels in the milk.

(Key words: Alxa bactrian camel, colostrum, milk, chemical composition)

Abbreviation key: $\mathbf{N F C M}=$ nonfat camel milk, $\mathbf{P P}=$ postpartum, $\mathbf{T N}=$ total nitrogen, $\mathbf{W P N}=$ whey protein nitrogen.

\section{INTRODUCTION}

There are different species of camels belonging to the genus camelus; the one-humped dromedary camel (Camelus dromedarius) and the two-humped bactrian camel (Camelus bactrianus) (Sawaya et al., 1984). The total population of camels in the world is about 18 million, of which 16 million are dromedaries, and 2 million are bactrians (Alhadrami, 2003). The dromedaries were domesticated about $3000 \mathrm{BC}$ in Arabia (Mehaia et al., 1995), and are found particularly in arid and semiarid zones of North and East Africa, the Indian subcontinent, and Saudi Arabia. Dromedaries are mainly used for milk production, whereas the bactrians, more prevalent in desert and semidesert areas of northwestern China and Mongolia, are mainly used for working and wool production. There are also some bactrian camels in Afghanistan and Tajikistan, where camel milk is mainly used for feeding young colts. Camel milk is an important nutrition source for inhabitants in arid and semiarid areas (Farah, 1996). Unlike other milk-producing animals, camels can thrive under extreme hostile conditions of temperature, drought, and lack of pasture, and still produce milk (Yagil and Etzion, 1980).

Milk-producing camels can be divided into 3 categories: high milk yield (more than $3000 \mathrm{~L} / \mathrm{yr}$ ), medium milk yield (1500 to $3000 \mathrm{~L} / \mathrm{yr}$ ), and low milk yield (less than $1500 \mathrm{~L} / \mathrm{yr}$ ). Only high and medium milk yield cam- 
els are suitable for milk production. Marecha (Pakistan), Al-Majaheim (also called Al-Njdeiah, Saudi Arabia), Sirtawi (Libya), Fakhreya (Libya), and Arvana (Turkmenistan, Uzbekistan, Kazakhstan, Afghanistan, and Iraq) are the major breeds of high milk yield camels in the world (Alhadrami, 2003).

There are 3 fine breeds of Camelus bactrianus in China, namely Xinjiang camel, Alxa bactrian camel, and Sunite camel. Alxa camels can be further divided into Gobi and Desert camels based on their stature, physical features, and breeding distinctions. In 1982, China had more than 250,000 Alxa camels. By 2001, the Alxa camel population numbered only 80,000 , which constituted less than $30 \%$ of the total camel population of 300,000 in China (H. Zhang and J. G. Wang, 2002, unpublished data). The rapid decline in the population of Alxa camel is mainly due to serious grassland desertification and low profit for raising these animals.

Alxa camels are reared mainly by natural grazing in different herd sizes ranging from 10 to 100 camels with a grazing radius of 40 to $50 \mathrm{~km}$. The female comes into heat for the first time at the age of 4 to $5 \mathrm{yr}$ old, and the breeding season lasts from mid-December until midApril. Pregnancy lasts 395 to $405 \mathrm{~d}$ and lactation takes place during February-August. An Alxa camel can produce 0.25 to $1.5 \mathrm{~kg}$ of milk daily in addition to the amount taken by the calf. The milk yield in the first 3 mo of lactation is higher than during the rest of lactation (H. Zhang and J. G. Wang, 2002, unpublished data). Camel milk is one of the important sources of food for local people. It can be used for making various dairy products such as butter, yogurt, cheese, and milk tea.

The general composition of camel milk varies in various parts of the world with a range of 3.5 to $4.5 \%$ protein, 3.4 to $5.6 \%$ lactose, 3.07 to $5.50 \%$ fat, 0.7 to $0.95 \%$ ash, and 12.1 to $15 \%$ TS (Gnan and Sheriha, 1986). This wide variation in the constituents of milk may be attributed to factors such as breed, age, the number of calvings, nutrition, management, the stage of lactation, and the sampling technique used (Abu-Lehia, 1987; Alshaikh and Salah, 1994). In general, the composition of camel milk is similar to milk from cattle and goats.

The information about camel milk chemistry is very limited in China. The objective of this work was to study the chemical composition and protein fractions of camel milk from the Alxa breed (Camelus bactrianus) in Inner Mongolia during lactation.

\section{MATERIALS AND METHODS}

\section{Animals}

Ten 5-yr-old Alxa bactrian female camels close to giving birth for the first time were randomly selected from different herds that are fed natural grazing. The camels, which belonged to the Alxa nomads in Inner Mongolia, were kept under muster management before giving birth and after parturition. All camels in the study were fed the same diet $(50 \%$ cornstalk $+50 \%$ dry clover) supplemented with $1.5 \mathrm{~kg}$ of grain concentrate (70\% corn $+30 \%$ soybean cake after oil extraction) and $30 \mathrm{~g}$ of table salt for each animal daily.

\section{Collection of Milk Samples}

Sampling started immediately following parturition at $2,12,24,36,48$, and $72 \mathrm{~h}$, and $5,7,15,30$, and 90 d postpartum (there was very little milk collected after d 90). All the samples collected were stored at $-40^{\circ} \mathrm{C}$ until analysis. The samples taken at the same stage of lactation were thawed, pooled, and portions were taken for analyses.

\section{Analyses of TS, Fat, Ash, and Lactose}

Total solids were determined gravimetrically after drying in a forced-draft oven at $105^{\circ} \mathrm{C}$ until a steady weight was achieved. Fat percentage was determined according to the method of Röse-Gottlieb, and ash content was measured gravimetrically (Aggarawala and Sharma, 1961). Lactose content was determined by the difference of TS minus other solid components.

\section{Determination of Protein Fractions}

Nitrogen content was determined by the Kjeldahl method. A nitrogen conversion factor of 6.38 was used for calculation of protein contents of milk samples and various fractions. The concentrations of total nitrogen (TN), whey protein nitrogen (WPN), casein N, and NPN were analyzed according to the procedure of Guo et al. (2001).

\section{Fatty Acid Analysis}

For fatty acid analysis, lipids were extracted from the milk samples by the Röse-Gottlieb cold extraction method (Pearson, 1977). Methyl esters of fatty acids were prepared using the method of Sheppard and Iverson (1975) and assayed using a Shimadzu GC-9A gas chromatograph (Shimadzu Corp., Tokyo, Japan) equipped with a flame-ionization detector according to the procedure by Gorban and Izzeldin (2001). The fatty acids were identified by comparison of retention time with known standards and were expressed as percentage of total fatty acids.

\section{Mineral and Vitamin Analysis}

Levels of $\mathrm{Ca}, \mathrm{K}, \mathrm{Na}$, and $\mathrm{Cl}$ in the milk samples were determined with an atomic absorption spectrophotome- 
ter (Hitachi U-2000, Tokyo, Japan) according to standard methods (AOAC, 1980). Phosphorus content was determined spectrophotometrically using the procedure of Watanabe and Olsen (1965). Concentrations of vitamins $\mathrm{A}, \mathrm{C}, \mathrm{D}, \mathrm{E}, \mathrm{B}_{1}, \mathrm{~B}_{2}$, and $\mathrm{B}_{6}$ were measured by fluorescence spectrometry as outlined in a Chinese standard method (GB/T 5413-1997; General inspection procedure for infant and young baby formula food and powdered milk).

\section{Electrophoresis}

Freeze-dried nonfat camel milks (NFCM) were prepared from the milk samples collected during the study period [ $2 \mathrm{~h}$ to $90 \mathrm{~d}$ postpartum (PP)]. Protein profiles in each sample were examined by SDS-PAGE under reducing conditions according to Laemmli (1970). The experiment was performed using a Mini-Protean II Cell (BioRad Laboratories, Hercules, CA) with a $4 \%$ acrylamide stacking gel and a $12 \%$ separating gel. Bovine milk protein standards including lactoferrin, BSA, $\alpha_{\mathrm{s}^{-}}$ $\mathrm{CN}, \beta$-CN, $\kappa$-CN, $\beta$-LG, and $\alpha$-LA from Sigma Chemical Co. (St. Louis, MO) were used for comparison. A BenchMark protein ladder (Invitrogen Corporation, Carlsbad, $\mathrm{CA}$ ), consisting of proteins ranging in molecular weight from 10 to $220 \mathrm{kDa}$, was used as a molecular weight standard. Electrophoresis was carried out under constant voltage $(200 \mathrm{~V})$ until the dye front was within 3 $\mathrm{mm}$ of the bottom edge of the gel. Gels were stained with 0.1\% Coomassie Brilliant Blue R-250 in 10:40:50 acetic acid:methanol:water ( $\mathrm{vol} / \mathrm{vol} / \mathrm{vol})$ and destained in the same solvent system without dye.

\section{Densitometry}

Quantitative analyses of electrophoretic separations of camel milk proteins were performed using the GelPro Analyzer 3.1 software from Media Cybernetics (Silver Spring, MD). Images of wet gels were acquired and converted from color to 8-bit gray images, and contrast was optimized so that the reference scale stretched from 0 (black) to 255 (white). One-dimensional gel image analyses (recognition of lanes and bands, calculation of molecular weight and amount of each band) were performed automatically by the software.

\section{Statistical Analyses}

Data were analyzed by a GLM procedure of the Fisher's protected-least-significant-difference test using SAS software (SAS Institute Inc., Cary, NC). This test combines ANOVA with comparison of differences between the means of the treatments at the significance level of $P<0.05$.

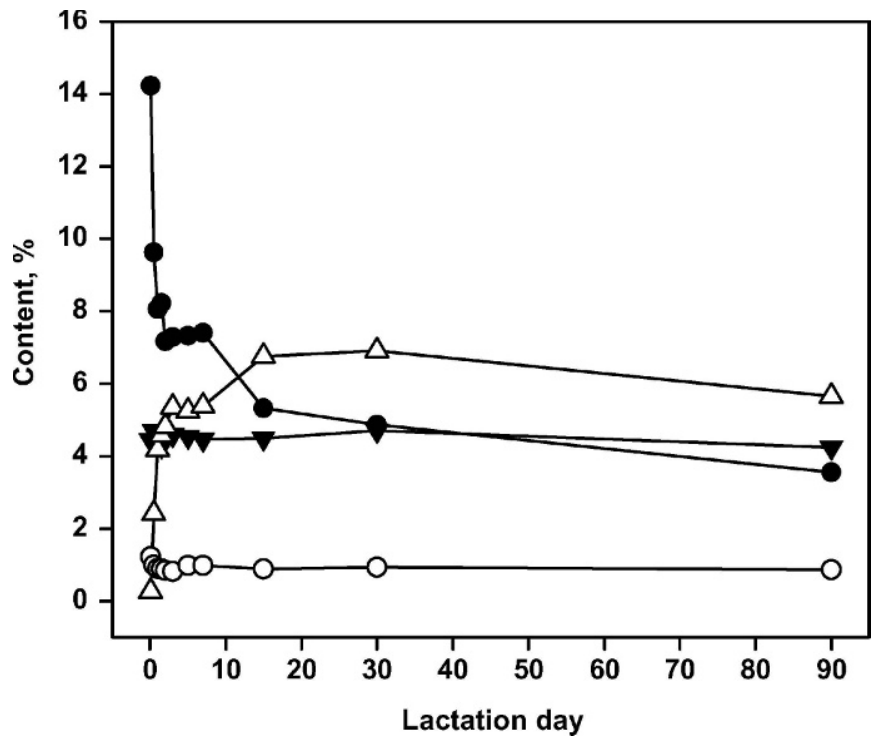

Figure 1. Changes in protein $(\bullet)$, lactose $(\boldsymbol{\nabla})$, fat $(\triangle)$, and ash $(O)$ contents of Alxa bactrian camel milk during the 90 -d lactation period.

\section{RESULTS AND DISCUSSION}

\section{Gross Composition}

Changes in gross composition (protein, lactose, fat, ash, and TS) of Alxa camel colostrum and milk during the 3-mo lactation period are shown in Figure 1. Colostrum is produced for the first week, after which the secretion is considered regular milk (Gorban and Izzeldin, 1997).

There was a sharp decline in protein content from 14.23 to $9.63 \%$ within the first $12 \mathrm{~h}$. It continued decreasing gradually to reach $7.17 \%$ on d 2 of lactation, stabilized between $\mathrm{d} 2$ to 7 , and further decreased to $5.32,4.87$, and $3.55 \%$ at $\mathrm{d} 15,30$, and 90 , respectively. A similar trend was observed in Najdi camel colostrum (Abu-Lehia et al., 1989), where the protein content decreased from 13.00 to $5.12 \%$ within the first $24 \mathrm{~h}$ and further decreased to $4.02 \%$ on d 10 of lactation. Ohri and Joshi (1961) also reported a protein content decreased from $14.49 \%$ at the first milking day to $3.95 \%$ on d 6 of lactation in Indian camel colostrum. In contrast, Kazakhstan camel colostrum exhibited higher protein content $(19.4 \%)$ at parturition, and then decreased quickly to $3.6 \%$ within $2 \mathrm{~d}$ (Bestuzheva, 1958). Moreover, the mean protein contents in pooled colostrum (1 to $7 \mathrm{~d}$ PP) and regular milk (10 to $240 \mathrm{~d} \mathrm{PP}$ ) of dromedary camels in Saudi Arabia were 5.82 and $3.27 \%$, respectively (Gorban and Izzeldin, 1997), which were lower than those of Alxa camel.

The lactose content remained relatively stable during the study period from parturition up to 3 mo PP. The 
values of the lactose content of Alxa camel milk ranged from 4.24 to $4.44 \%$, whereas for dromedary camel milk, the values ranged from 2.56 to $5.80 \%$ (Mehaia et al., 1995; Gorban and Izzeldin, 1997). It is well known that bovine colostrum is also rich in most of its components such as protein, fat, serum proteins, and ash. The only component that is low in bovine colostrum in the first days after parturition and increases subsequently is lactose (Merin et al., 2001b). The same was reported for camel milk (Yagil and Etzion, 1980; Abu-Lehia, 1991), but was not confirmed in the present study or the work by Merin et al. (2001b), possibly due to the determination of lactose by difference.

The fat content of Alxa camel colostrum at $2 \mathrm{~h}$ after parturition was as low as $0.27 \%$, which was similar to Kazakhstan camel (Bestuzheva, 1958) and Najdi camel (Abu-Lehia et al., 1989). Its content significantly increased to $4.18 \%$ within the first $48 \mathrm{~h}$, peaked at $6.91 \%$ after $1 \mathrm{mo}$, followed by a slight decline to $5.65 \%$ at 90 d PP. A similar trend was noted for dromedary camel milk as reported by Merin et al. (2001b), where the fat content of colostrum initially was low, then reached its highest levels after about a week and then decreased to its average value thereafter. This pattern was in contrast to those of the bovine, sheep, and goat colostrum (Abu-Lehia et al., 1989). In general, the Alxa camel milk was higher in fat compared with the reported values for dromedary camel (Mehaia et al., 1995; Gorban and Izzeldin, 1997; Guliye et al., 2000).

At $2 \mathrm{~h}$ after parturition, the ash content of Alxa camel colostrum was $1.22 \%$. This was higher than that of Jordanian (0.57\%) and Najdi (0.99\%) camels and lower than that of Indian (2.6\%) and Kazakhstan (3.8\%) camel colostrum as reported by Yagil and Etzion (1980), AbuLehia et al. (1989), Ohri and Joshi (1961), and Bestuzheva (1958), respectively. The ash content decreased significantly to $0.99 \%$ in the first $12 \mathrm{~h}$, and then fluctuated slightly thereafter with percentages ranging from 0.82 to $0.98 \%$. In contrast, a steady decrease in ash content of colostrum was reported for the Najdi camel (Abu-Lehia et al., 1989). Ash content ranged from 0.6 to $1.0 \%$ for dromedary camels (Mehaia et al., 1995; Gorban and Izzeldin, 1997; Guliye et al., 2000), suggesting that camel milk may provide a satisfactory level of minerals for consumers (El-Amin and Wilcox, 1992).

The TS content (data not shown) of colostrum showed a rapid decrease from 20.16 to $17.73 \%$ during the first $12 \mathrm{~h}$, likely attributed to the sharp decrease in the protein content over the same period. The TS content remained relatively stable (17.39 to $18.22 \%$ ) from $12 \mathrm{~h}$ to $30 \mathrm{~d}$ PP, and then decreased to $14.31 \%$ on $\mathrm{d} 90$ of lactation. Bestuzheva (1958) and Abu-Lehia et al. (1989) also reported a sharp decrease in TS content in colostrum during the first days of lactation for Kazakh- stan and Najdi camels. According to Mehaia et al. (1995), the TS content ranged from 10.0 to $14.4 \%$ in dromedary camel milk.

The contents of protein, lactose, fat, ash, and TS of Alxa bactrian camel milk at $90 \mathrm{~d}$ PP were 3.55, 4.24, $5.65,0.87$, and 14.31 , respectively, which were comparable to the data $(3.80,5.10,5.39,0.69$, and 14.98$)$ reported by Kheraskov (1961) for the bactrian camel in Kazakhstan. Under the same conditions, the chemical composition of camel milk varies from species to species (Mehaia et al., 1995; Gaili et al., 2000), and the largest variations during lactation were in TS and fat contents. Guliye et al. (2000) showed that the stage of lactation did not significantly affect the constituents in regular camel milk. According to Alhadrami (2003), the composition of camel milk is similar to bovine milk, and the average values of protein, lactose, fat, ash, and TS contents of camel milk were $3.4,3.7,4.1,0.7$, and $13.1 \%$, respectively.

\section{Nitrogen Distribution}

Changes in nitrogen distribution of Alxa camel milk during the first $90 \mathrm{~d}$ of lactation are shown in Table 1. Total $\mathrm{N}$ decreased quickly within the first day. This decrease was attributed mainly to the decrease in WPN. No further major decrease in TN was observed between d 1 and 7. The TN content began to decrease again, reaching $0.56 \mathrm{~g} / 100 \mathrm{~mL}$ on $\mathrm{d} 90$. This decrease was likely attributed to the decrease in both casein $\mathrm{N}$ and WPN contents over the same period. Relatively higher content of TN was observed in Alxa camel milk compared with the published data $(0.42$ to $0.53 \mathrm{~g} / 100 \mathrm{~mL})$ for dromedary camel (Mehaia et al., 1995).

Nonprotein $\mathrm{N}$ contents were found to vary considerably (from 0.03 to $0.08 \mathrm{~g} / 100 \mathrm{~mL}$ ) throughout the period of this study. However, the concentrations of NPN as percentage of $\mathrm{TN}$ showed a trend of increase over the $90 \mathrm{~d}$ and the values were 7.89 and $7.14 \%$ on $\mathrm{d} 30$ and d 90, respectively (Table 1). These results fall within the range of the published data (4.6 to 15.9\%) for dromedary camel (Farah, 1993; Mehaia et al., 1995). Nonprotein $\mathrm{N}$ content in bovine milk has been reported in the range 0.025 to $0.035 \mathrm{~g} / 100 \mathrm{~g}$ of milk (Walstra et al., 1984). Results of this study show that the average values of the NPN content in regular milk of Alxa camel are higher than those of bovine milk, which is in agreement with other reports (Abu-Lehia, 1987; Mehaia et al., 1995). According to Mehaia et al. (1995), the NPN fraction has biological importance due to the content of free amino acids (such as taurine), B vitamins, and nucleotides and their precursors such as orotic acid.

Casein is the major protein component of milk and certain dairy products such as cheese. The content of 
Table 1. Nitrogen distribution (g/100 mL; $\%$ of $\mathrm{N}$ given in parentheses) in colostrum and milk of Alxa bactrian camel during the lactation period. ${ }^{1}$

\begin{tabular}{|c|c|c|c|c|c|}
\hline Time & Total N & $\mathrm{NPN}$ & Casein $\mathrm{N}$ & $\begin{array}{l}\text { Whey protein } \mathrm{N} \\
\text { (WPN) }\end{array}$ & WPN:Casein N \\
\hline $2 \mathrm{~h}$ & $\begin{array}{l}2.23 \pm 0.02^{\mathrm{a}} \\
(100.00)\end{array}$ & $\begin{array}{l}0.06 \pm 0.02^{\text {abcd }} \\
(2.69)\end{array}$ & $\begin{array}{l}0.86 \pm 0.00^{\mathrm{b}} \\
(38.57)\end{array}$ & $\begin{array}{l}1.31 \pm 0.01^{\mathrm{a}} \\
(58.74)\end{array}$ & $60: 40$ \\
\hline $12 \mathrm{~h}$ & $\begin{array}{l}1.51 \pm 0.0^{\mathrm{b}} \\
(100.00)\end{array}$ & $\begin{array}{l}0.04 \pm 0.01^{\mathrm{de}} \\
(2.65)\end{array}$ & $\begin{array}{l}0.80 \pm 0.01^{\mathrm{d}} \\
(52.98)\end{array}$ & $\begin{array}{l}0.67 \pm 0.01^{b} \\
(44.37)\end{array}$ & $46: 54$ \\
\hline $24 \mathrm{~h}$ & $\begin{array}{l}1.26 \pm 0.01^{\mathrm{d}} \\
(100.00)\end{array}$ & $\begin{array}{l}0.03 \pm 0.06^{\mathrm{e}} \\
(2.38)\end{array}$ & $\begin{array}{l}0.82 \pm 0.00^{c} \\
(65.08)\end{array}$ & $\begin{array}{l}0.41 \pm 0.01^{\mathrm{c}} \\
(32.54)\end{array}$ & $33: 67$ \\
\hline $36 \mathrm{~h}$ & $\begin{array}{l}1.29 \pm 0.00^{c} \\
(100.00)\end{array}$ & $\begin{array}{l}0.08 \pm 0.01^{\mathrm{a}} \\
(6.20)\end{array}$ & $\begin{array}{l}0.82 \pm 0.00^{c} \\
(63.57)\end{array}$ & $\begin{array}{l}0.39 \pm 0.01^{\mathrm{d}} \\
(30.23)\end{array}$ & $32: 68$ \\
\hline $48 \mathrm{~h}$ & $\begin{array}{l}1.12 \pm 0.02^{f} \\
(100.00)\end{array}$ & $\begin{array}{l}0.07 \pm 0.01^{\mathrm{abc}} \\
(6.25)\end{array}$ & $\begin{array}{l}0.81 \pm 0.015^{\mathrm{c}} \\
(72.32)\end{array}$ & $\begin{array}{l}0.24 \pm 0.01^{\mathrm{f}} \\
(21.43)\end{array}$ & $23: 77$ \\
\hline $72 \mathrm{~h}$ & $\begin{array}{l}1.14 \pm 0.03^{\mathrm{ef}} \\
(100.00)\end{array}$ & $\begin{array}{l}0.06 \pm 0.03^{\text {cde }} \\
(5.26)\end{array}$ & $\begin{array}{l}0.82 \pm 0.01^{c} \\
(71.93)\end{array}$ & $\begin{array}{l}0.27 \pm 0.00^{\mathrm{e}} \\
(23.68)\end{array}$ & $25: 75$ \\
\hline $5 \mathrm{~d}$ & $\begin{array}{l}1.15 \pm 0.01^{\mathrm{ef}} \\
(100.00)\end{array}$ & $\begin{array}{l}0.07 \pm 0.01^{\mathrm{ab}} \\
(6.09)\end{array}$ & $\begin{array}{l}0.86 \pm 0.01^{b} \\
(74.78)\end{array}$ & $\begin{array}{l}0.21 \pm 0.01^{g} \\
(18.26)\end{array}$ & $20: 80$ \\
\hline $7 \mathrm{~d}$ & $\begin{array}{l}1.16 \pm 0.01^{\mathrm{e}} \\
(100.00)\end{array}$ & $\begin{array}{l}0.08 \pm 0.02^{\mathrm{a}} \\
(6.89)\end{array}$ & $\begin{array}{l}0.90 \pm 0.02^{\mathrm{a}} \\
(77.59)\end{array}$ & $\begin{array}{l}0.18 \pm 0.01^{\mathrm{h}} \\
(15.52)\end{array}$ & $17: 83$ \\
\hline $15 \mathrm{~d}$ & $\begin{array}{l}0.83 \pm 0.01^{\mathrm{g}} \\
(100.00)\end{array}$ & $\begin{array}{l}0.05 \pm 0.01^{\text {bcde }} \\
(6.02)\end{array}$ & $\begin{array}{l}0.66 \pm 0.01^{\mathrm{e}} \\
(79.52)\end{array}$ & $\begin{array}{l}0.12 \pm 0.01^{\mathrm{i}} \\
(14.46)\end{array}$ & $15: 85$ \\
\hline $30 \mathrm{~d}$ & $\begin{array}{l}0.76 \pm 0.02^{\mathrm{h}} \\
(100.00)\end{array}$ & $\begin{array}{l}0.06 \pm 0.02^{\text {abcd }} \\
(7.89)\end{array}$ & $\begin{array}{l}0.61 \pm 0.01^{f} \\
(80.26)\end{array}$ & $\begin{array}{l}0.09 \pm 0.01^{j} \\
(11.84)\end{array}$ & $13: 87$ \\
\hline $90 \mathrm{~d}$ & $\begin{array}{l}0.56 \pm 0.01^{\mathrm{i}} \\
(100.00)\end{array}$ & $\begin{array}{l}0.04 \pm 0.01^{\mathrm{de}} \\
(7.14)\end{array}$ & $\begin{array}{l}0.45 \pm 0.01^{g} \\
(80.36)\end{array}$ & $\begin{array}{l}0.07 \pm 0.01^{\mathrm{k}} \\
(12.50)\end{array}$ & $14: 86$ \\
\hline
\end{tabular}

a,b,c,d,e,f,g,h,i,j,k The same letters in a column denote means that are not significantly different $(P>0.05)$ based on Fisher's protected least significant difference test for multiple comparisons.

${ }^{1}$ Data are means of triplicate determinations.

casein $\mathrm{N}$ remained relatively stable (ranging from 0.80 to $0.90 \mathrm{~g} / 100 \mathrm{~mL}$ ) during the first week of lactation (Table 1). After that, casein $\mathrm{N}$ began to decrease and reached $0.45 \mathrm{~g} / 100 \mathrm{~mL}$ on $\mathrm{d} 90$. The percentage of TN of milk as casein is called "casein number," which is an important parameter for determining the suitability of milk for cheese production. The casein number of Alxa camel milk was found to increase steadily from $38.57 \%$ at parturition up to $79.52 \%$ at $15 \mathrm{~d} \mathrm{PP}$; and stabilizing around $80 \%$ thereafter. The casein number of Alxa camel milk was higher than that of dromedary camel milk (Farah, 1993; Mehaia et al., 1995), but very close to the reported data $(79.2 \%)$ for bovine milk (AbuLehia, 1987).

Highest concentration $(1.31 \mathrm{~g} / 100 \mathrm{~mL})$ of WPN was observed in Alxa camel colostrum at parturition (Table 1). The WPN content decreased by about $50 \%$ within the first $12 \mathrm{~h}$ and continued to decline steadily thereafter reaching $0.07 \mathrm{~g} / 100 \mathrm{~mL}$ on $\mathrm{d} 90$, whereas the levels of WPN as percentage of TN in camel milk decreased gradually from $58.74 \%$ at parturition to $12.5 \%$ at d 90 . According to Elagamy (2000), the biological value of whey protein is the highest among the milk proteins due to its antimicrobial factors such as lysozyme, lactoferrin, and immunoglobulins. Because Alxa camel colostrum contains more WPN, it is of higher biological value than regular milk, suggesting the importance of colostrum in providing the newborn with immunity. On the other hand, the WPN content and the ratio of WPN to casein $\mathrm{N}$ of Alxa camel milk were lower compared with dromedary camel milk (Farah, 1993; Mehaia et al., 1995).

\section{Fatty Acid Profile}

Changes in fatty acid composition of Alxa camel's milk fat during the period of this study are shown in Figure 2. Although there were some variations in the fatty acid content, the level of even-numbered saturated fatty acids $\left(\mathrm{C}_{12: 0}-\mathrm{C}_{18: 0}\right)$ in colostrum were lower and polyunsaturated fatty acids $\left(\mathrm{C}_{18: 1}-\mathrm{C}_{18: 3}\right)$ were higher than in regular milk. The predominant saturated fatty acids were $\mathrm{C}_{14: 0}, \mathrm{C}_{16: 0}$, and $\mathrm{C}_{18: 0}$, whereas the main polyunsaturated fatty acid was $\mathrm{C}_{18: 1}$, regardless of the stage of lactation.

Even-numbered saturated fatty acids $\left(\mathrm{C}_{12: 0}-\mathrm{C}_{18: 0}\right)$ in Alxa camel milk at $90 \mathrm{~d}$ PP accounted for $57.54 \%$ of total fatty acids with $\mathrm{C}_{16: 0}, \mathrm{C}_{18: 0}$, and $\mathrm{C}_{14: 0}$ as the major components $(30.12,15.15$, and $11.49 \%$, respectively). These results are similar to those of dromedary camel milk reported in the literature (Sawaya et al., 1984; Abu-Lehia, 1989; Gorban and Izzeldin, 2001). Our data confirmed that saturated fatty acid in camel milk is lower than that in bovine milk (Gorban and Izzeldin, 2001). On the other hand, polyunsaturated fatty acids $\left(\mathrm{C}_{18: 1} \mathrm{C}_{18: 3}\right)$ in Alxa camel milk at $90 \mathrm{~d} \mathrm{PP}$ accounted 


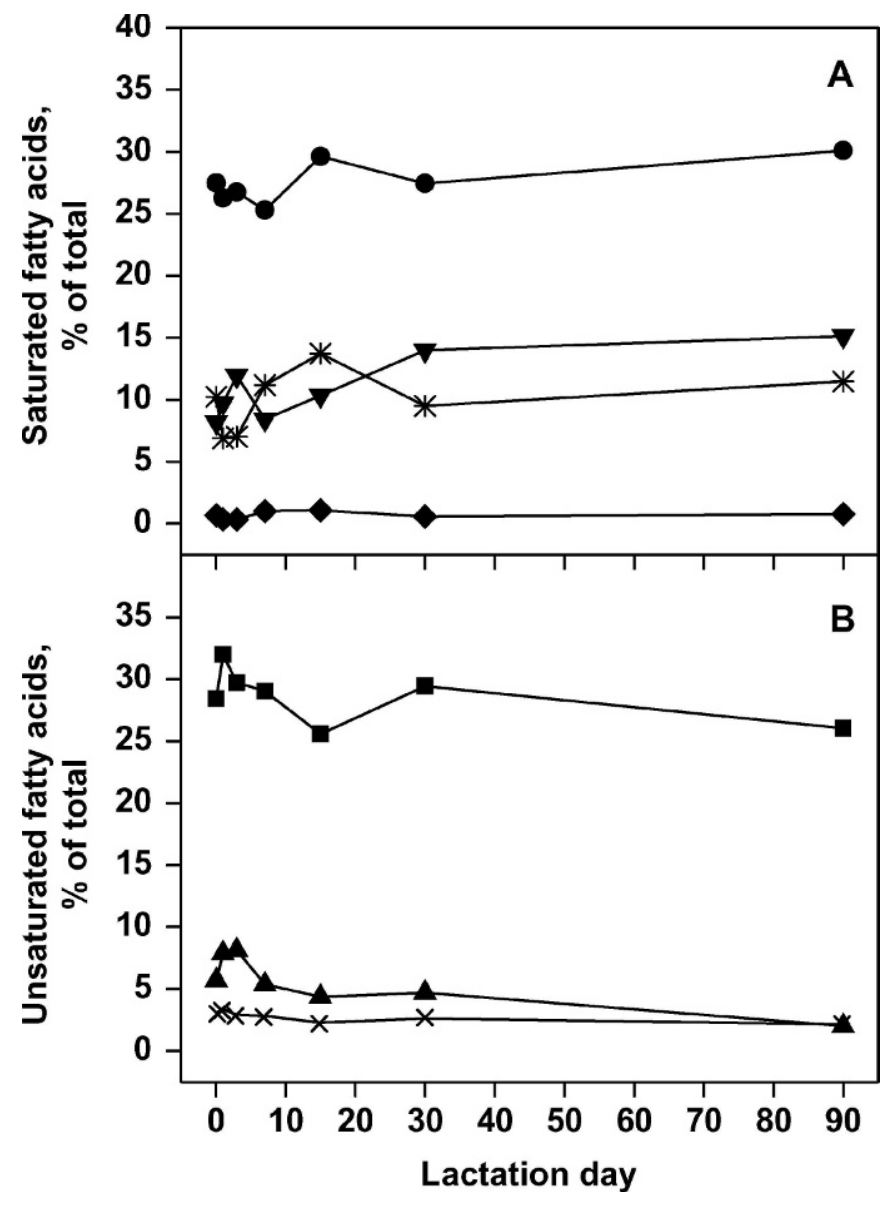

Figure 2. Changes in fatty acid concentrations of Alxa camel's milk fat during lactation. (A) Even-numbered saturated fatty acids: $\mathrm{C}_{12: 0}(\bullet), \mathrm{C}_{14: 0}(*), \mathrm{C}_{16: 0}(\bullet)$, and $\mathrm{C}_{18: 0}(\boldsymbol{\nabla}) ;(\mathrm{B})$ Polyunsaturated fatty acids: $\mathrm{C}_{18: 1}(\boldsymbol{\square}), \mathrm{C} 18: 2(\boldsymbol{\Delta})$, and $\mathrm{C}_{18: 3}(\times)$.

for $30.25 \%$ of total fatty acids, mainly $\mathrm{C}_{18: 1}(26.05 \%)$. This result agrees with the report by Abu-Lehia (1989) but is higher than the values reported by Gorban and Izzeldin (2001) for Najdi camel. According to Gnan and Sheriha (1986), camel's milk fat contained high levels of polyunsaturated acids, which are essential for human nutrition. Short-chain fatty acids $\left(\mathrm{C}_{4: 0}-\mathrm{C}_{8: 0}\right)$ of camel milk have been reported to be in the range 0.1 to $1.2 \%$, which were considerably lower than that of bovine milk (Abu-Lehia, 1989; Farah, 1993; Gorban and Izzeldin, 2001; Alhadrami, 2003). Factors that affect the fatty acid composition of camel milk include breed, feeding, composition of dietary fat, dietary protein, seasonality and region, and stage of lactation (Palmquist et al., 1993; Gorban and Izzeldin, 2001).

\section{Minerals and Vitamins}

Figure 3 shows the changes of 4 major minerals (Ca, $\mathrm{P}, \mathrm{Na}$, and $\mathrm{K}$ ) and $\mathrm{Cl}$ contents in Alxa camel colostrum

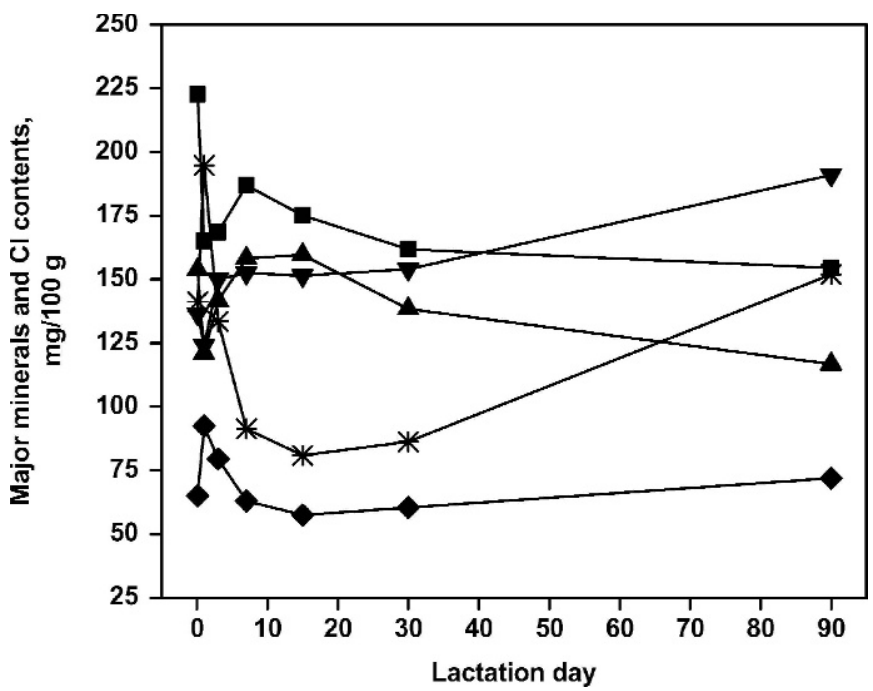

Figure 3. Changes in contents of $\mathrm{Ca}(\boldsymbol{\nabla}), \mathrm{P}(\boldsymbol{\Delta}), \mathrm{Na}(\bullet), \mathrm{K}(\boldsymbol{\nabla})$, and $\mathrm{Cl}(*)$ in Alxa bactrian camel milk during lactation.

and regular milk during lactation. The content of $\mathrm{Ca}$ showed a sharp decrease during the first day of lactation, after which it increased slightly up to $d 7$, and then decreased gradually to the lowest value of 154.57 $\mathrm{mg} / 100 \mathrm{~g}$ on $\mathrm{d} 90$. The $\mathrm{P}$ content showed a similar trend to Ca during the 90-d lactation period, but was lower than the Ca content throughout lactation. The contents of $\mathrm{Na}$ and $\mathrm{K}$ varied considerably during the lactation period but, in general, $\mathrm{Na}$ content was higher and $\mathrm{K}$ content was lower in colostrum than in milk. A large variation was found in $\mathrm{Cl}$ content throughout the lactation period with a concentration of $152.0 \mathrm{mg} / 100 \mathrm{~g}$ on $\mathrm{d} 90$. This value was slightly lower than the $\mathrm{Cl}$ content $(167.3 \mathrm{mg} / 100 \mathrm{~mL}$ ) reported by Guliye et al. (2000) for Bedouin camel milk, but considerably higher than that (43 mg/100 g) reported for Libyan camel milk (Gnan and Sheriha, 1986).

The major mineral contents $(\mathrm{Ca}, \mathrm{P}, \mathrm{Na}$, and $\mathrm{K})$ of Alxa camel milk were comparable to some of the data (30 to 197, 45 to 138,23 to 69 , and 60 to $214 \mathrm{mg} / 100$ $\mathrm{g}$, respectively) reported for dromedary camel, which showed a large variation among different studies (Farah, 1993; Mehaia et al., 1995; Gorban and Izzeldin, 1997). The variations in the major mineral contents of camel milk could be due to breed, feeding, stage of lactation, drought conditions, or analytical procedures (Farah, 1993; Mehaia et al., 1995). When compared with bovine milk, contents of $\mathrm{Ca}, \mathrm{P}, \mathrm{Na}$, and $\mathrm{K}$ in Alxa bactrian camel milk at $90 \mathrm{~d} \mathrm{PP}$ were substantially higher than those in bovine milk (124, 96.2, 57.5, and $126.0 \mathrm{mg} / 100 \mathrm{~mL}$, respectively) as reported by Mehaia et al. (1995). Although minerals comprise less than $1 \%$ 


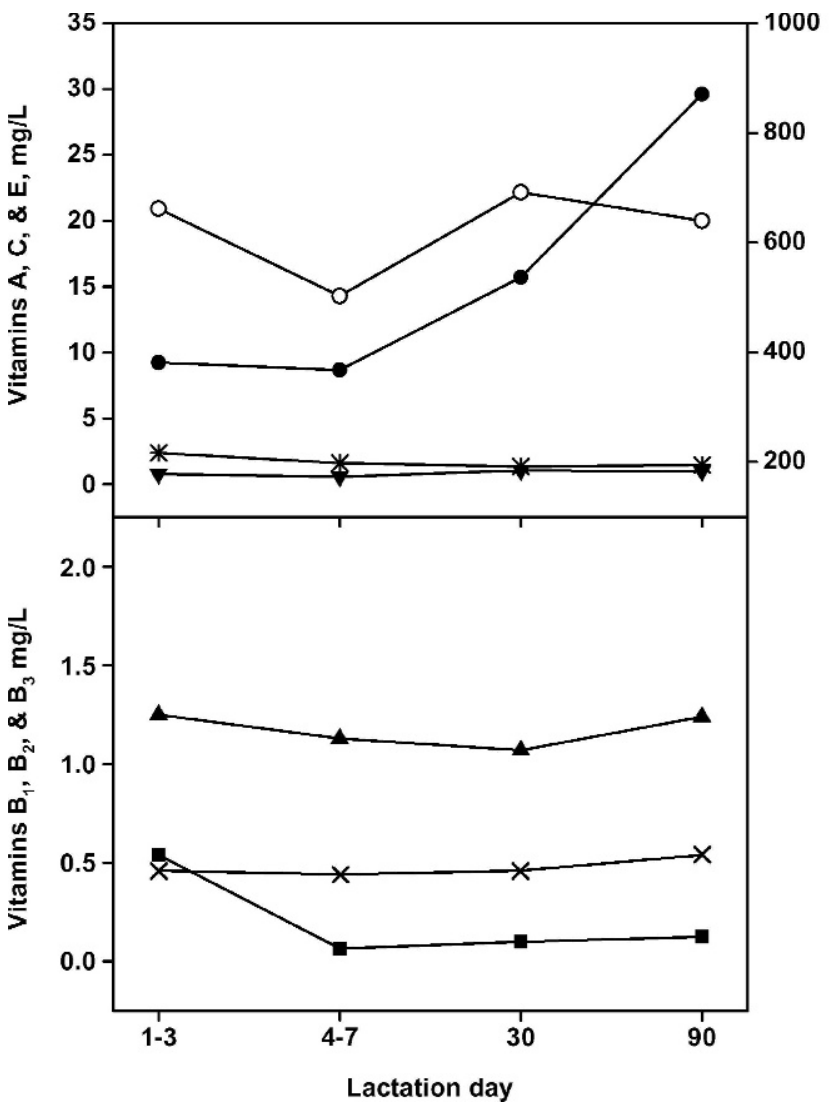

Figure 4. Changes in contents of vitamins $\mathrm{A}(\boldsymbol{\nabla}), \mathrm{C}(\bullet), \mathrm{D}(\mathrm{O}), \mathrm{E}(*)$, $\mathrm{B}_{1}(\boldsymbol{\square}), \mathrm{B}_{2}(\boldsymbol{\Delta})$, and $\mathrm{B}_{6}(\times)$ of Alxa bactrian camel milk during lactation.

of the milk, they are essential to the stability of milk proteins (caseins; Farah, 1993).

Figure 4 shows the contents of vitamins in Alxa camel colostrum and milk samples. In general, the levels in milk of vitamins $\mathrm{A}$ and $\mathrm{C}$ were higher and vitamins $\mathrm{E}$ and $B_{1}$ were lower than those in colostrum, whereas the contents of vitamins $\mathrm{D}, \mathrm{B}_{2}$, and $\mathrm{B}_{6}$ remained relatively stable throughout the study period. On d 90 of lactation, concentrations of vitamins $\mathrm{A}, \mathrm{C}, \mathrm{E}, \mathrm{B}_{1}, \mathrm{~B}_{2}$, and $\mathrm{B}_{6}$ in Alxa camel milk were found to be $0.97,29.60,1.45,0.12$, 1.24 , and $0.54 \mathrm{mg} / \mathrm{L}$, respectively. It is worth noting that little information is available in the literature regarding the content of vitamin D in camel milk. Our study revealed that the contents of vitamin D in Alxa camel milk on d 30 and 90 of lactation were 692 and $640 \mathrm{IU} / \mathrm{L}$, respectively.

According to the literature data, the range of vitamin $\mathrm{A}, \mathrm{C}, \mathrm{E}, \mathrm{B}_{1}, \mathrm{~B}_{2}$, and $\mathrm{B}_{6}$ contents of dromedary camel milk were 0.10 to $0.38,3$ to $36,0.2$ to $1.0,0.28$ to 0.90 , 0.42 to 2.0 , and 0.40 to $0.63 \mathrm{mg} / \mathrm{L}$, respectively (Farah, 1993; Alhadrami, 2003). Results from this study showed that Alxa camel milk had higher level of vitamins A and $\mathrm{E}$, but lower $\mathrm{B}_{1}$ compared with dromedary camel milk. When compared with bovine milk (Farah, 1993; Alhadrami, 2003), the contents of vitamins $B_{6}$ and $B_{12}$ of Alxa camel milk were comparable to those of bovine milk, whereas those of vitamins $\mathrm{A}, \mathrm{E}, \mathrm{B}_{1}$, and $\mathrm{B}_{2}$ were lower. On the other hand, the level of vitamin $\mathrm{C}$ of Alxa camel milk was close to that of Najdi camel milk (Sawaya et al., 1984) but higher than that of bovine milk. The availability of a moderate amount of vitamin $\mathrm{C}(29.60 \mathrm{mg} / \mathrm{L})$ in camel milk is of significant relevance to the human diet in areas where green vegetables and fruits are hard to find (Sawaya et al., 1984).

\section{SDS-PAGE and Densitometry}

Gel electrophoretic patterns of freeze-dried NFCM prepared from raw camel milk samples obtained during the 3-mo lactation period are shown in Figure 5. Quantitative determinations of the milk proteins were carried out by densitometry analysis on the gels using the GelPro Analyzer software and the data (expressed as percentage of total protein) were presented in Table 2. It is shown that Alxa camel colostrum contained considerably high level of serum proteins in the first days of lactation (Figure 5), which decreased quickly thereafter. Caseins showed an opposite trend to serum proteins, increasing significantly, to a maximum level in about $1 \mathrm{wk}$ (Table 2). The SDS-PAGE results agreed well with those for WPN and casein $\mathrm{N}$ based on nitrogen distribution analysis reported in this study.

In lanes 1 to 11 of Figure 5 (for NFCM), it is possible to observe protein bands with apparent molecular weights of $11.9,26.0,31.2,70.3$, and $80.0 \mathrm{kDa}$, respectively, which were comparable to bovine $\alpha$-LA (11.2 $\mathrm{kDa}), \beta-\mathrm{CN}(26.0 \mathrm{kDa}), \alpha_{\mathrm{s}}-\mathrm{CN}(31.0 \mathrm{kDa})$, BSA $(65.4$ $\mathrm{kDa})$, and lactoferrin $(76.9 \mathrm{kDa})$ as shown in lane BM. In addition, bands of $\sim 42, \sim 55 \mathrm{kDa}$ (designated as MW42 and MW55, respectively), and a band at about $210 \mathrm{kDa}$ (more intense in colostrum) were also observed in lanes 1 to 11 . Merin et al. (2001a) observed a similar band of $\sim 42 \mathrm{kDa}$ in dromedary camel milk. With respect to the band of $210 \mathrm{kDa}$, it is presumed to be immunoglobulins (mainly IgG). A molecular weight of about $160 \mathrm{kDa}$ from chromatography for IgG in dromedary camel milk has been reported (Merin et al., 2001a). On the other hand, Alxa camel colostrum and milk showed the absence of proteins having electrophoretic mobility comparable with bovine $\beta$-LG $(16.1 \mathrm{kDa})$ as shown in lane BM (Figure 5). This result is in agreement with published data (Ochirkhuyag et al., 1998; Elagamy, 2000; Merin et al., 2001a). According to Ochirkhuyag et al. (1998), $\beta$-LG is responsible for some of the observed allergies to bovine milk.

The major whey protein bands in Alxa camel colostrum belong to camel serum albumin, Ig, $\alpha$-LA, and 


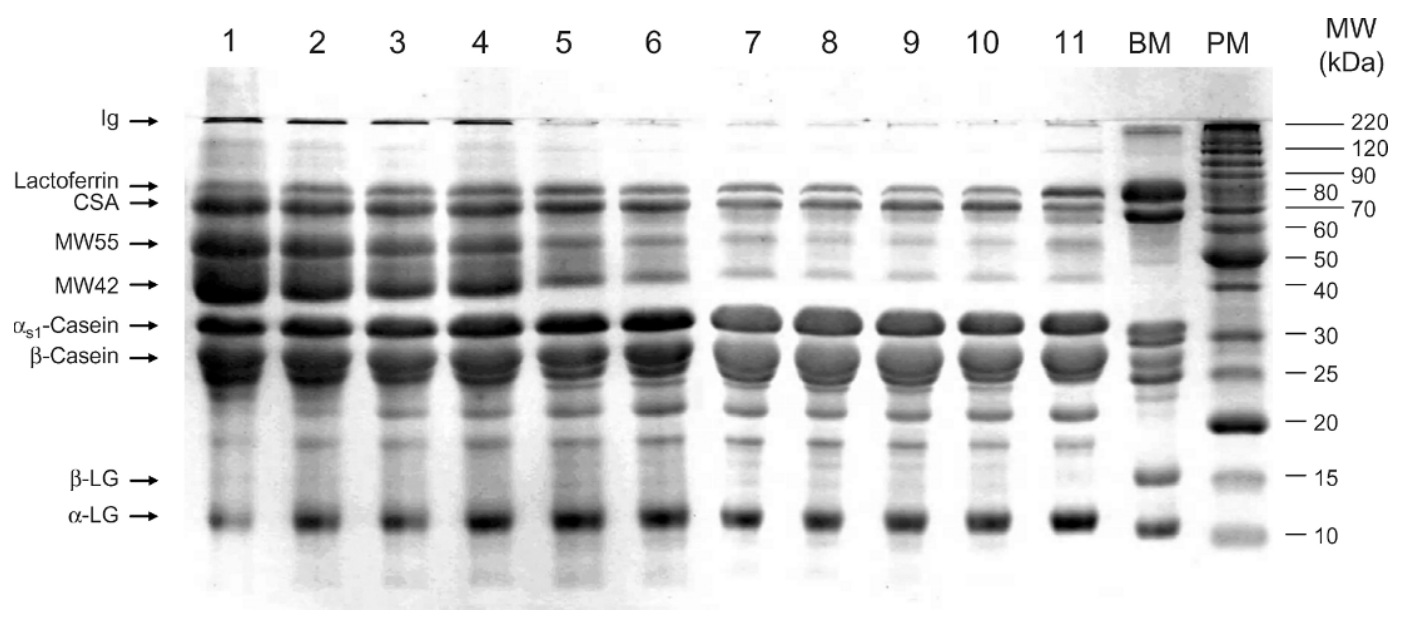

Figure 5. Sodium dodecyl sulfate-PAGE of freeze-dried nonfat Alxa camel milk samples: Lanes 1 to 11 are milk samples obtained at 2 , $12,24,36,48$, and $72 \mathrm{~h}$, and $5,7,15,30$, and $90 \mathrm{~d}$ postpartum, respectively; BM is the sample of bovine milk proteins including lactoferrin, $\mathrm{BSA}, \alpha_{\mathrm{s}}-\mathrm{CN}, \beta-\mathrm{CN}, \kappa$-CN, $\beta$-LG, and $\alpha$-LA, respectively; PM = protein marker; CSA = camel serum albumin; MW55 and MW42 = unknown fractions with molecular weight of 55 and $42 \mathrm{kDa}$, respectively.

lactoferrin, whereas in camel milk, the bands of camel serum albumin, $\alpha$-LA, and lactoferrin were found with high intensities (Figure 5). The 2 unknown fractions (MW42 and MW55) also showed high intensities in Alxa camel colostrum. However, the nature of the 2 protein fractions has yet to be determined. According to AbuLehia et al. (1989), the colostrum consists mainly of Ig and other serum proteins, which provide the newborn calves with nutrients and passive immunity and support the growth of symbiotic intestinal flora. It is clear that, in Alxa camel colostrum, the percentage level of Ig, MW42, and MW55 declined quickly, whereas casein and $\alpha$-LA started at a low level and increased gradually until they reach their normal concentrations in the milk
(Table 2). On the other hand, the electrophoretic patterns of Alxa camel colostrum and milk samples showed 2 main protein bands (designated as camel $\alpha_{\mathrm{s} 1}-\mathrm{CN}$ and $\beta$-CN) in the area of caseins (Figure 5) with estimated molecular weights of 31 and $26 \mathrm{kDa}$, respectively, similar to the published data for dromedary camel milk (Larsson-Raznikiewicz and Mohamed, 1986). Compared with bovine casein, the bands of camel casein have lower electrophoretic mobilities (Figure 5), which is in agreement with the results reported by Farah and Farah-Riesen (1985). According to Larsson-Raznikiewicz and Mohamed (1986), bovine caseins contain strongly hydrophilic and hydrophobic regions that may give under- or overestimated values of molecular weight

Table 2. Changes of protein components (\% of total protein) in nonfat camel milk (NFCM) prepared from Alxa camel colostrum and milk samples obtained during the lactation period. ${ }^{1}$

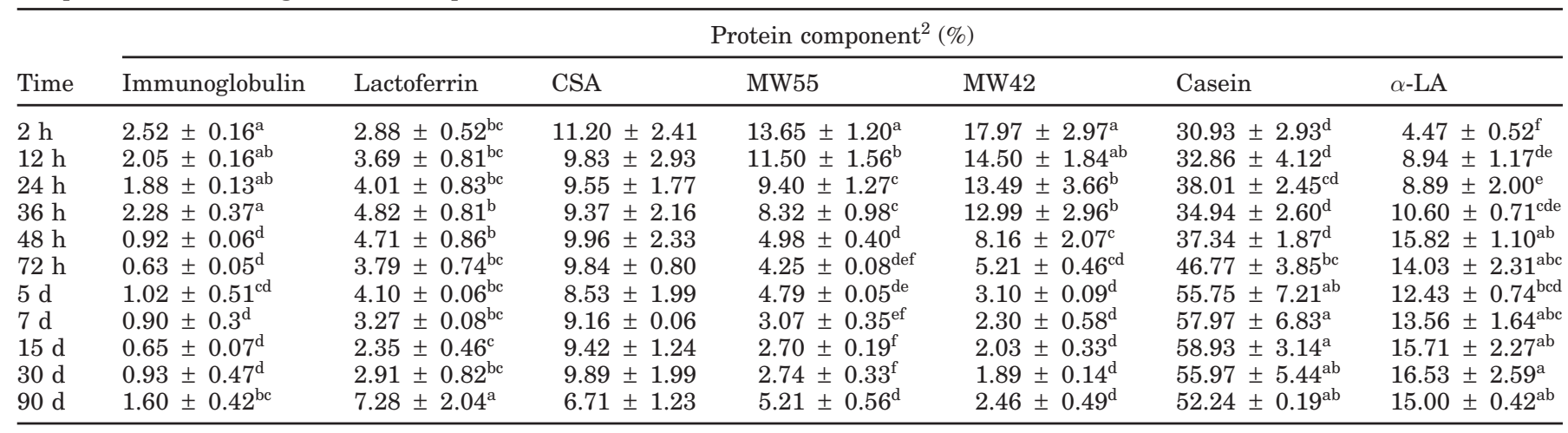

a,b,c,d,e,f The same letters in a column denote treatments that are not significantly different $(P>0.05)$ based on Fisher's protected least significant difference multiple comparisons.

${ }^{1}$ Based on the quantitative data obtained from densitometry analysis of the SDS-PAGE gels. Data are means of 2 experiments.

${ }^{2} \mathrm{CSA}=$ Camel serum albumin, MW55 = unknown protein fraction with molecular weight around $55 \mathrm{kDa}$, MW42 = unknown protein fraction with molecular weight around $42 \mathrm{kDa}$. 
determinations from SDS-PAGE. The same could be assumed for camel caseins.

\section{CONCLUSIONS}

There were higher protein, lower fat and casein N, and markedly higher WPN contents in Alxa camel colostrum than those in milk. The casein number of Alxa camel milk was similar to that of bovine milk. Both colostrum and regular milk had considerable level of polyunsaturated fatty acids. The levels of vitamins A and $\mathrm{C}$ were lower, and those of vitamins $\mathrm{E}$ and $\mathrm{B}_{1}$ were higher in colostrum compared with those in milk. Vitamin D content was found to be around $600 \mathrm{IU} / \mathrm{L}$ in both colostrum and milk of Alxa camel. The colostrum is rich in immunoglobulins and serum albumin, whereas levels of casein and $\alpha$-LA were relatively low and increased gradually until the average values reached the levels of regular milk. It is shown that there is lack of $\beta$-LG in the Alxa camel milk. As information about camel milk chemistry is limited, especially in China, more systematic studies are needed in this area.

\section{REFERENCES}

Abu-Lehia, I. H. 1987. Composition of camel milk. Milchwissenschaft 42:368-371.

Abu-Lehia, I. H. 1989. Physical and chemical characteristics of camel milkfat and its fractions. Food Chem. 34:261-271.

Abu-Lehia, I. H. 1991. Nitrogen distribution and mineral contents of camel colostrum. Aust. J. Dairy Technol. 46:82-84.

Abu-Lehia, I. H., I. S. Al-Mohizea, and M. El-Beheri. 1989. Physical and chemical characteristics of camel colostrum. Aust. J. Dairy Technol. 44:34-36.

Aggarawala, A. C., and R. M. Sharma. 1961. A Laboratory Manual of Milk Inspection. 4th ed. Asia Publishing House, Bombay, India.

Alhadrami, G. A. 2003. Camel. Pages 616-622 in Encyclopedia of Dairy Science. H. Roginski, J. W. Fuquay, and P. F. Fox, ed. Academic Press, London, UK.

Alshaikh, M. A., and M. S. Salah. 1994. Effect of milking interval on secretion rate and composition of camel milk in late lactation. J. Dairy Res. 61:451-456.

AOAC. 1980. Official Methods of Analysis. 13th ed. Association of Official Analytical Chemists, Washington, DC.

Bestuzheva, K. T. 1958. Composition of the colostrum and milk of camels. Dairy Sci. Abstr. 20: Abstr. no. 2937.

Elagamy, E. I. 2000. Effect of heat treatment on camel milk proteins with respect to antimicrobial factors: A comparison with cows' and buffalo milk proteins. Food Chem. 68:227-232.

El-Amin, F. M., and C. J. Wilcox. 1992. Milk composition of Majaheim camels. J. Dairy Sci. 75:3155-3157.

Farah, Z. 1993. Composition and characteristics of camel milk. J. Dairy Res. 60:603-626.
Farah, Z. 1996. Camel Milk: Properties and Products. SKAT, Swiss Centre for Development Cooperation in Technology and Management, St. Gallen, Switzerland.

Farah, Z., and M. Farah-Riesen. 1985. Separation and characterization of major components of camel milk casein. Milchwissenschaft 40:669-671.

Gaili, E. S. E., M. M. Al-Eknah, and M. H. Sadek. 2000. Comparative milking performance of three types of Saudi camels (Camelus dromedarius). J. Camel Pract. Res. 7:73-76.

Gnan, S. O., and A. M. Sheriha. 1986. Composition of Libyan camel's milk. Aust. J. Dairy Technol. 41:33-35.

Gorban, A. M. S., and O. M. Izzeldin. 1997. Mineral content of camel milk and colostrum. J. Dairy Res. 64:471-474.

Gorban, A. M. S., and O. M. Izzeldin. 2001. Fatty acids and lipids of camel milk and colostrum. Int. J. Food Sci. Nutr. 52:283-287.

Guliye, A. Y., R. Yagil, and F. D. D. Hovell. 2000. Milk composition of Bedouin camels under semi-nomadic production system. J. Camel Pract. Res. 7:209-212.

Guo, M. R., P. H. Dixon, Y. W. Park, J. A. Gilmore, and P. S. Kindstedt. 2001. Seasonal changes in the chemical composition of commingled goat milk. J. Dairy Sci. 84(E. Suppl.):E79-E83.

Kheraskov, S. G. 1961. Composition, properties, and nutritive value of camel milk. Vop. Pitan. 20:69-72.

Laemmli, U. K. 1970. Cleavage of structural proteins during the assembly of the head of Bacteriophage T4. Nature 227:680-685.

Larsson-Raznikiewicz, M., and M. A. Mohamed. 1986. Analysis of the casein content in camel (Camelus dromedarius) milk. Swed. J. Agric. Res. 16:13-18.

Mehaia, M. A., M. A. Hablas, K. M. Abdel-Rahman, and S. A. ElMougy. 1995. Milk composition of Majaheim, Wadah and Hamra camels in Saudi Arabia. Food Chem. 52:115-122.

Merin, U., S. Bernstein, A. Bloch-Damti, R. Yagil, C. Van-Creveld, P. Lindner, and N. Gollop. 2001a. A comparative study of milk serum proteins in camel (Camelus dromedarius) and bovine colostrum. Livest. Prod. Sci. 67:297-301.

Merin, U., S. Bernstein, C. van Creveld, R. Yagil, and N. Gollop. 2001b. Camel (Camelus dromedarius) colostrum and milk composition during the lactation. Milchwissenschaft 56:70-74.

Ochirkhuyag, B., J. M. Chobert, M. Dalgalarrondo, Y. Choiset, and T. Haertle. 1998. Characterization of whey proteins from Mongolian yak, khainak, and bactrian camel. J. Food Biochem. 22:105-124.

Ohri, S. P., and B. K. Joshi. 1961. Composition of camel milk. Indian Vet. J. 38:514-516.

Palmquist, D. L., A. D. Beaulieu, and D. M. Barbano. 1993. Feed and animal factors influencing milk fat composition. J. Dairy Sci. 76:1753-1771.

Pearson, D. 1977. The Chemical Analysis of Foods. Chemical Publishing Company, Inc., New York, NY.

Sawaya, W. N., J. K. Khalil, A. Al-Shalhat, and H. Al-Mohammad. 1984. Chemical composition and nutritional quality of camel milk. J. Food Sci. 49:744-747.

Sheppard, A. J., and J. L. Iverson. 1975. Esterification of fatty acids for gas-liquid chromatographic analysis. J. Chromatogr. Sci. 13:448-452.

Walstra, P., R. Jenness, and H. T. Badings. 1984. Dairy Chemistry and Physics. John Wiley \& Sons, New York, NY.

Watanabe, F. S., and S. R. Olsen. 1965. Test of an ascorbic acid method for determining phosphorus in water and $\mathrm{NaHCO}_{3}$ extracts from soil. Soil Sci. Soc. Am. Proc. 29:677-678.

Yagil, R., and Z. Etzion. 1980. Effect of drought condition on the quality of camel milk. J. Dairy Res. 47:159-166. 